\title{
Review
}

Fetal Diagnosis and Therapy

\section{Long-Term Follow-Up of Intrauterine Growth Restriction: Cardiovascular Disorders}

\author{
Elena Demicheva Fatima Crispi
}

Fetal and Perinatal Medicine Research Group, Institut d'Investigacions Biomèdiques August Pi i Sunyer, University of Barcelona, Department of Maternal-Fetal Medicine, Institut Clínic de Ginecologia, Obstetrícia i Neonatologia, Hospital Clinic, and Centro de Investigación Biomédica en Red en Enfermedades Raras, Barcelona, Spain

\section{Key Words}

Intrauterine growth restriction - Cardiovascular disease .

Fetal programming $\cdot$ Long-term consequences

\begin{abstract}
In the modern world, cardiovascular disorders are the leading cause of mortality in developed countries, which in most cases undergo a long subclinical phase that can last decades before the first clinical symptoms appear. Aside from the well-known risk factors related to lifestyle and genetics, there is growing evidence that in a proportion of cases, the predisposition to cardiovascular disease lies in prenatal life. Moreover, numerous historical cohort studies and animal models have shown a clear association between low birth weight and increased cardiovascular mortality in adulthood, including increased risk of hypertension, diabetes, dyslipidemia and coagulation disorders in children and adults. Besides premature birth, low birth weight in the majority of the cases is caused by intrauterine growth restriction (IUGR), which affects up to $10 \%$ of all births. Several clinical and experimental studies showed that IUGR fetuses present signs of cardiac dysfunction in utero that persist postnatally and may condition higher cardiovascular risk later in life. The present review discusses the importance of the long-term cardiovascular follow-up of the patients who suffered early
\end{abstract}

or late IUGR in utero, particularly with regard to the longterm epidemiological studies in adults, prospective studies in children and the possible mechanisms that trigger IUGR and cardiovascular programming. Considering the high prevalence of IUGR and the progressing availability of intervention strategies, it is of the highest clinical relevance to detect cardiovascular risks as early as possible, to introduce timely preventive interventions and to adapt the lifestyle, in order to improve the long-term cardiovascular health outcome of IUGR cases.

Copyright $\odot 2013$ S. Karger AG, Basel

\section{Introduction}

Fetal Programming of Adult Cardiovascular Disease

In the modern world, cardiovascular disorders are the leading cause of mortality in developed countries, with an estimated $23 \%$ of all disease burdens and over 4 million deaths each year in Europe [1]. For many years the cardiovascular condition was thought to be determined by the genetic factors and lifestyle, defined by the amount of physical activity and quality of nutrition in early adulthood. In most cases, cardiovascular diseases (CVDs) undergo a long subclinical phase that can last decades before the first clinical symptoms appear [2]. However, already 
in 1989, David Barker's group [3] in Southampton, UK, established a direct correlation between low birth weight and CVD in adulthood, including hypertension and cardiovascular mortality. This discovery was confirmed and widely explored in the last few decades of intensive research in both humans [4] and animals [5]. Taken together, the collective data obtained suggests that the complex interaction between genetic constitution and the prenatal and early postnatal environment determines the growth and development of the fetus and defines the susceptibility to certain disorders in adult life, like hypertension, diabetes, dyslipidemia and coagulation disorders [6]. This phenomenon is known as 'fetal programming', when an insult in utero leads to functional changes in key organs remaining in postnatal life and leading to a greater risk of various diseases in adulthood [5, 7-9]. The rapid cell proliferation and differentiation during fetal growth are very sensitive to any of the even smallest changes damaging to the environment that can lead to permanent alterations in structural and functional constitution, which then may persist into the adult life [6].

\section{Definition and Classification of IUGR}

Besides premature birth, low birth weight in the majority of the cases is caused by intrauterine growth restriction (IUGR) [10]. According to the 2001 classification of the American College of Obstetricians and Gynecologists, IUGR is diagnosed when a fetus does not reach its growth potential, characterized by the birth weight and body mass lower than normal with respect to the number of gestational weeks below the tenth percentile [11]. IUGR is a major cause of perinatal morbidity and mortality [12] and may complicate $7-10 \%$ of all pregnancies, depending on the population, geographical location and the standard growth curves used as reference in different countries.

Most IUGR causes are associated with placental insufficiency. The gestational age at which the IUGR develops is of major significance for the outcome of pregnancy [13]. Therefore, IUGR is also classified by early and late onset. Early IUGR is diagnosed by the classical Doppler flow measurements before 34 weeks of gestation, recognized as an increase in impedance to blood flow at the umbilical artery and subsequent fetal vasodilation mechanism to maintain cerebral oxygen supply [14]. The severity of placental dysfunction and its impact on the fetal cardiovascular status is then determined by the grade and the progression rate of Doppler abnormalities. Late-onset IUGR after 34 weeks differs by clinical manifestations, patterns of deterioration, and severity of placental dys- function, which normally is milder and with normal umbilical artery blood flow $[15,16]$. Unfortunately, the lack of information in the literature makes it very difficult to differentiate between early and late IUGR, and most of the studies fail to identify the origins of IUGR in order to select the correct patient cohorts accordingly.

\section{IUGR and Cardiovascular Remodeling}

Assessing cardiovascular conditions in utero, multiple studies revealed that fetuses which have been diagnosed with IUGR have cardiac systolic and diastolic dysfunction [17], with increased E/A ratios and myocardial performance index [18] and reduced myocardial tissue velocities [19]. Moreover, it has been postulated that IUGR fetuses experience hypertension and hypervolemia due to hemodynamic redistribution and adaptation to hypoxia and insufficient nutrition [20]. Further follow-up evaluation of these children and experimental evidence have demonstrated that cardiovascular remodeling, triggered in response to the stress conditions in utero, persist as a permanent feature in postnatal life [5] including dilated cardiomyopathy-like heart remodeling and vascular dysfunction, increased blood pressure and carotid intimamedia thickness. These findings are similar to those of cardiac remodeling associated with sustained pressure and volume overload. The closer analysis revealed that molecular changes in the cardiac myocyte contractile machinery in IUGR fetuses are similar to those described in dilated cardiomyopathy and diastolic heart failure [21]. At the same time, sarcomere length is decreased, which results in a less efficient contraction. In addition, gene expression of the sarcomere regulatory proteins is altered and these alterations persist in adulthood as well [21]. Again, these molecular changes are in line with alterations described in other models of cardiac disease driven by high pressure and/or volume [22].

In addition to the obvious importance of the intrauterine environment during critical developmental stages, the conditions of early childhood are likewise of great significance. The accelerated postnatal growth, so-called 'catch-up' growth, is one of the most important triggers of hypertension in small for gestational age children who are more likely to suffer cardiovascular complications in adult life [23].

Importance of Early Diagnosis and Prevention of CVD Fetal developmental programming, besides determining a cardiovascular health condition in adult life, also provides an exclusive and potent approach of intervention to prevent CVD and improve the health condition in 
adulthood. The current 'European guidelines on CVD prevention in clinical practice' highly support the clinical follow-up of patients with a high risk of CVD, although IUGR patients are unfortunately still not included in this group [24]. The importance of early diagnosis and consequent monitoring of IUGR has been stressed by recent studies showing an improved cardiovascular outcome in children due to the timely applied preventive measures like dietary $\omega-3$ supplementation $[25,26]$.

In this review we will discuss the importance of longterm cardiovascular follow-up of patients who suffered early or late IUGR in utero, particularly with regard to the long-term epidemiological studies in adults, prospective studies in children and the possible mechanisms that trigger IUGR and cardiovascular programming.

\section{Epidemiological Studies Supporting the Link between IUGR and Adult CVD}

After Barker and colleagues discovered in 1989 the apparent link between low birth weight and increased risk of death from CVD and stroke, the increasing number of subsequent studies confirmed these observations. Moreover, the correlation between low birth weight and hypertension was reported already in 1988 in a Swedish study analyzing a cohort of male army recruits who had been small at birth [27]. The described association was also confirmed later in men and women in several larger studies [28-31].

One of the main disadvantages of early epidemiological studies was a lack of a correct and complete follow-up for several decades [32]. These requirements, however, were achieved in the following study that included almost 15,000 Swedish men and women, with a $97 \%$ follow-up over a period of more than 50 years [33]. This study showed a strong correlation between lower birth weight and death rate from ischemic heart disease. A further large cohort study performed by the group of Rich-Edwards et al. [34] in 1997 in more than 120,000 American women revealed strong negative trends of recorded birth weight and incidents of non-fatal coronary heart disease and stroke.

The awareness of environmental influences that impair fetal and infant growth was increased after the report that men with the lowest birth weights and at 1 year of age had the highest death rates from ischemic heart disease [35]. An interesting observation was that despite the similar increase in general death rate in men and women inversely related to their lower birth weight, only men developed CVD in adult life [36].

Follow-Up of Intrauterine Growth

Restriction
Following the described observations, a hypothesis was proposed that the promotion of growth during prenatal and early postnatal life could improve cardiovascular conditions in adulthood, especially in boys who weighed $<3.5 \mathrm{~kg}$ [3]. Later, however, it was proven to be wrong, as in the cohort study in Finnish men the cardiovascular mortality was also increased as a result of the rapid weight gain in the first 3 years of life [37]. The increased mortality rate was also confirmed in obese men who had a BMI above average between 7 and 15 years of age [38]; moreover, this effect was greater in males born to obese mothers [39].

A study in women born short in length showed that an increase in height later in life was associated with the higher risk of mortality from coronary heart disease [40]. Since most of these women had tall mothers, it was suggested that their prenatal growth was constrained. Taken together, these data confirm that men and women with a lower birth weight and subsequent obesity in adulthood have the highest CVD risk [37].

Despite the certainty of the observations described above, one also needs to take into consideration the environmental factors that can have a great influence on the cardiovascular development. For example, a cohort study in South Africa showed the link between low birth weight and adult glucose intolerance and blood pressure elevation that occurs in young adults despite the lack of full catch-up growth as a consequence of a high-risk, disadvantaged environment of the population [41].

Taken together, the epidemiological evidence described above confirms the critical correlation between the early life environment and the major risk factors for CVD. Moreover, the collected data supports the great importance to identify early origins of the disease and to perform a thorough long-term follow-up of the high-risk patients (fig. 1).

\section{Prospective Cohort Studies in IUGR Children and Adolescents}

Further studies investigating the link between fetal growth restriction and development of CVD in postnatal life, particularly in children and adolescents, have confirmed a strong inverse correlation between birth weight and cardiovascular disorders.

The association between elevated blood pressure in children and low birth weight has been known for a decade following the collective strong evidence in the literature [42]. Already in 1997, one of the largest cohort stud- 
Fig. 1. Cardiovascular programming in IUGR. Cardiovascular programming is triggered by an insult in utero, which can lead to functional changes in key organs persisting in postnatal life and leading to a greater risk of various diseases in adulthood. Therefore, it is critical to intervene as early as possible in order to prevent CVD in adult life.

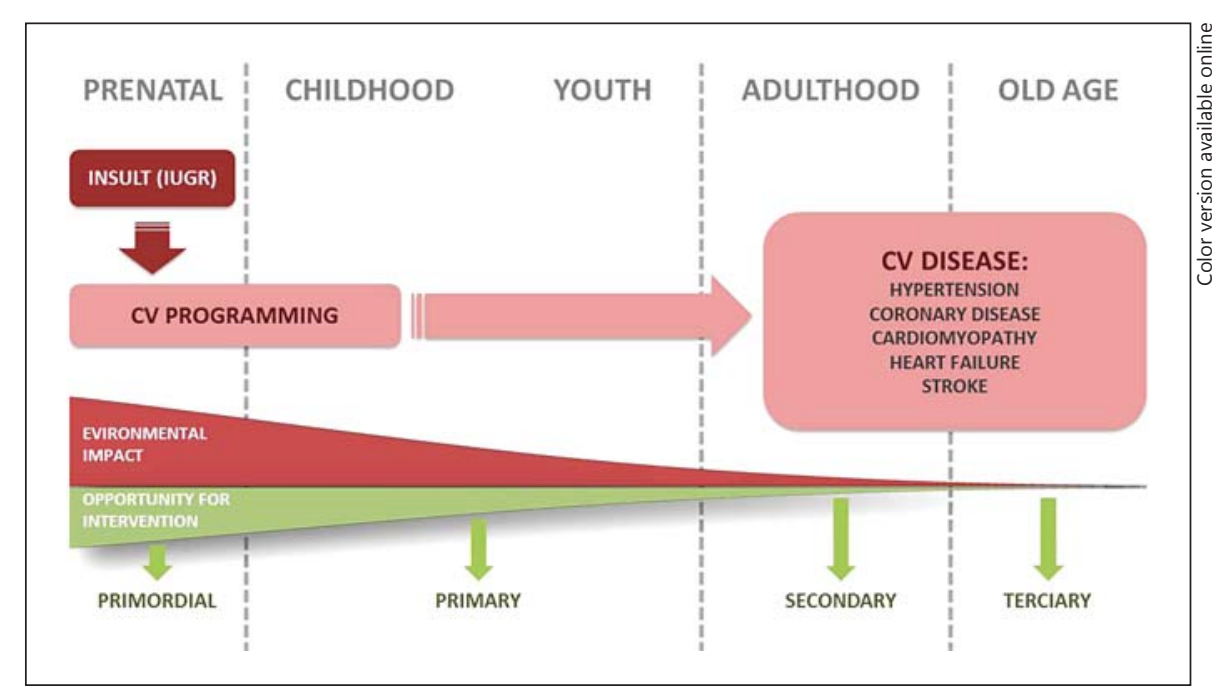

ies of almost 150,000 adolescents in Sweden showed that systolic blood pressure was significantly higher in young men who had the lowest birth weight, thus supporting the notion of a programming effect of fetal growth retardation in utero on hemodynamic regulation in early adult life [43].

The well-known Generation R study has showed that fetal hemodynamic patterns already change in the presence of reduced fetal growth while the fetus is still within the normal estimated fetal weight range. The condition of decreased fetal growth triggers cardiac remodeling and cardiac output that are consistent with a gradual increase in afterload and compromised arterial compliance [44].

Furthermore, our group has obtained consequent conclusive data in a prospective cohort study in children 3-6 years of age, suggesting that fetal cardiovascular programming is not exclusive for premature and severe forms of growth restriction, but it also occurs mildly in late-onset IUGR $[45,46]$, which often is referred to as small for gestational age $[47,48]$. In both early- and lateonset IUGR children, more globular hearts, reduced longitudinal motion and impaired relaxation were observed. Late-onset IUGR could compensate by increased radial function, while the more severe early-onset cases showed decreased radial function leading to lower stroke volume and increased heart rate in order to maintain cardiac output [49]. Additionally, both groups showed signs of vascular remodeling including increased blood pressure, as well as carotid intima-media thickness [49]. The significantly progressive increased aortic intima-media thickness and elevated blood pressure were also observed in another recent study in IUGR fetuses and infants at
18 months of age compared to control, suggesting predisposition of the infants to hypertension early in life and cardiovascular risk in adulthood [50].

\section{Proposed Mechanistic Pathways of IUGR}

Despite the many studies performed investigating different aspects of IUGR in human pregnancies, the pathophysiological processes underlying this disorder remain very complex and not completely understood. Various animal models have been developed and employed in order to clarify processes regulating fetal growth in normal conditions and IUGR, and to develop potential strategies of intervention.

Several possible risk factors have been proposed and evaluated in animal models as possible triggers of IUGR maternal nutrition, impairment of uteroplacental function and early exposure to harmful exogenous factors.

\section{Maternal Nutrition}

Fetal nutrition is the most critical factor that determines pregnancy outcome, and the strong correlation between maternal nutritional diet and fetal development was described already decades ago [51]. Since then, many animal studies have confirmed that the limitation of general food intake to pregnant animals to 30,50 or $70 \%$ of the regular free intake ad libitum, besides significantly lower birth weight, also programs increased blood pressure, decreased angiogenesis, and increased risk of endothelial dysfunction in the adult undernourished offspring compared to the offspring of the control dams [52-54]. 
The programming of these symptoms, however, depends on the severity and on the gestational period of the restriction $[55,56]$. Interestingly, birth weight is significantly decreased in rodents only if the general caloric restriction is carried out late in pregnancy from days 7 or 15 to 21 [57], but not during gestational days 7-14.

Compared to the balanced reduction in maternal nutrient intake, the specific restriction of maternal protein in rat programs more consistent rise of blood pressure in adult life [58-60]. Since the early 1990s, many studies have shown that a maternal low-protein diet during the gestational period leads among other symptoms to lower birth weight, hypertension, vascular dysfunction, increased angiotensin-converting enzyme activity, decreased nephron number and increased oxidative stress in adulthood [56, 61, 62]. Endothelial dysfunction has also been shown to be associated with maternal low-protein diet in a non-litter-bearing species [63]. Moreover, recent studies have also shown that maternal protein restriction also affects the lifespan of the offspring. Similar to general caloric restriction, duration and timing of the maternal low-protein diet are also very important. If dams are fed the low-protein diet only for single weeks, the magnitude of the diet's effect on postnatal blood pressure is greatest when the low-protein diet is consumed during the last week of gestation [64].

\section{Impairment of Uteroplacental Function}

Induction of IUGR by maternal nutritional manipulation provides easy and reproducible tools to study fetal programming, but they fail to reproduce the restriction of oxygen supply [65], which is considered to be among most critical factors in fetal development. As an alternative, one of the most frequently used methods to study mechanisms of IUGR is to induce placental insufficiency by the direct restriction of vascular perfusion.

The permanent ligation of both uterine arteries leads to hypoxia, decreased growth factor availability and hypoglycemia [66]. The high degree of blood flow obstruction results in a significantly lower birth weight and programs reduced nephron numbers, hypertension, type 2 diabetes and proteinuria in the adult offspring [55]. The mortality rate of this model is, however, much higher compared with nutrition manipulation models. A permanent ligation of one uterine artery performed at mid-gestation in guinea pig causes alterations of the placenta, heart, aorta and kidneys in the offspring [67]. Moreover, growth-restricted fetuses and neonates are chronically hypoxic [68], hyperglycemic [69] and have an altered brain development [70]. A selective ligation of $30-50 \%$ of uteroplacental vessels late in gestation programs pronounced cardiovascular Doppler changes in fetuses, particularly in the ductus venosus, which partially reproduces the hemodynamic features of the IUGR condition in human fetuses [71]. Other interventions mimicking placental insufficiency, such as uteroplacental embolization, carunclectomy or maternal hyperthermia [72], result in a similar phenotype and cardiovascular dysfunction as that in rodent surgical models [73], suggesting a common underlying mechanism of cardiovascular programming.

\section{Prenatal Exposure to Exogenous Factors}

Studying the possible mechanisms of fetal cardiovascular programming, the group of Langley-Evans [74] has discovered that hypertension induced by fetal exposure to a maternal low-protein diet in the rat can be prevented by treatment with metyrapone - an inhibitor of maternal glucocorticoid synthesis. It is also known that maternal exposure to glucocorticoids has been associated with reduced birth weight and adult disease in humans $[75,76]$. Consequently, it has been shown that treatment of pregnant rats with the synthetic glucocorticoid dexamethasone results in a lower birth weight and persistent elevation of arterial blood pressure in the adult offspring $[77,78]$. Identical results were obtained after treatment of pregnant rats with carbenoxolone - an inhibitor of placental enzyme, $11 \beta$-hydroxysteroid dehydrogenase-2 (11 $\beta$-HSD2), which metabolizes corticosterone to the inert 11-dehydrocorticosterone [79]. Interestingly, the model of low-protein diet treatment of pregnant rats has also been associated with a decreased activity of $11 \beta-\mathrm{HSD} 2$ in placenta, which would in turn increase access of endogenous maternal glucocorticoids to the fetus [80]. Moreover, a $40-50 \%$ reduction in food intake of pregnant animals results in an increase in maternal and neonatal glucocorticoids in rats [81] and in guinea pigs [82]. Taken together, the collective data points towards the pivotal role of the placental $11 \beta$-HSD2 in the programming of hypertension and that excessive exposure of the fetus to the glucocorticoids would inevitably lead to the reduction in birth weight and elevated blood pressure which persists into adult life [83].

It was also found that exogenous environmental factors like high altitude can act independently from other factors to reduce birth weight. Increased maternal ventilation and ventilator response to hypoxia during pregnancy raises arterial oxygen saturation and correlates with the offspring's birth weight [84]. Similarly, the exposure of pregnant rats to chronic hypoxia $\left(10.5 \% \mathrm{O}_{2}\right)$ between days 15 and 21 of gestation leads to an increase in the percentage and size of binucleated myocytes, an in- 
crease in apoptotic cells in the fetal heart [85] and in an increased susceptibility of the adult heart to ischemic-reperfusion injury [86]. The increased cell death in fetal heart could lead to cardiac hypertrophy, resulting in asymmetric enlargement of the heart's chambers and an increased cardiovascular risk in adulthood.

It has also been known for many years that maternal smoking is one of the factors that has a strong association with fetal growth restriction, dramatically affecting the placental vessels due to nicotine and hypoxia [87-89]. Moreover, fetal exposure to maternal smoking might also lead to adverse cardiovascular effects, like hypertension, that persists into adulthood [90, 91]. Accordingly, it has been shown in the animal experimental model that daily inhalation of tobacco throughout gestation causes a significantly reduced birth weight in rat offspring $[92,93]$. Similar adverse effects of growth restriction are observed after fetal exposure to alcohol [94] or harmful drugs like cocaine [95]. The adverse effects of fetal alcohol exposure are clearly demonstrated in various animal models, including inhalation of ethanol vapor, direct intraperitoneal injection and oral exposure by gavage, diet or drinking water [96].

These conclusive data indicate that cardiac overload due to the changes in placental function or maternal nutrition may result in a change in the developmental profile of cardiomyocytes and cardiac function in adult life.

\section{Possible Mechanisms and Therapeutic Targets}

Various interlinking mechanisms have been proposed to explain the effect of early insults on cardiovascular health condition in adult life. After investigating structural and physiological changes in different tissues, the most promising field currently is epigenetic regulation of organ development and molecular processes in pre- and early postnatal life [97-100]. The fetal environment can trigger various epigenetic modifications, changes in gene expression pattern without alterations of DNA sequence, and thus lead to different phenotypes of the offspring [97, $99,100]$. Three main processes are identified that can silence, activate or regulate the level and timing of the gene expression: DNA methylation, histone modifications (acetylation, methylation, ubiquitination, phosphorylation or ADP-ribosylation), and microRNAs (miRNAs). These mechanisms appear to work together in a complex interconnected network to accurately regulate gene expression, since DNA methylation and/or histone modifications can alter the miRNAs expression and vice versa. It has been shown that specific nutrients can affect methyl group supply. For example, folate, vitamin $B_{12}$ and methionine can increase the availability of the methyl groups when their restriction can lead to obesity, insulin resistance and hypertension in the offspring [101, 102]. Similarly, in rats fed a low-protein diet, gene expression of various pulmonary and cardiac genes was significantly altered in the placentas and offspring. Additionally, the genes coding several enzymes involved in various epigenetic processes have been found to be affected in organs like the lungs, heart, kidney and liver, and the severity was inversely correlated with the onset of organ function [103]. These complex epigenetic modifications could explain the low birth weight, kidney maldevelopment and hypertension, as well as increased angiotensin-converting enzyme activity $[59,104]$.

Apart from epigenetic changes during early development, modifications in metabolism and in the morphology and physiology of the cardiovascular and renal systems are the main mechanisms of fetal programming that leads to the adverse long-term effects discussed in this review. In particular, enhanced vasoconstrictor responses, related to increased angiotensin receptor 1 (AT1) expression and superoxide production, have been reported to be involved in the cardiovascular programming pathway $[61,105]$. This might be the consequence of an increased reactive oxygen species production, a decreased expression of endothelial NO synthase or soluble guanylate cyclase, resulting in decreased availability of NO.

In parallel to cardiovascular alterations, a decreased number of nephrons and different stages of kidney maldevelopment have been observed in several models studying fetal programming $[106,107]$. These modifications in renal development, as well as alterations in the activity of the renin-angiotensin system, renal nerves and tubular transporters [108], have been proposed as the most potential mechanisms to program hypertension in postnatal life.

Quite a few studies have already shown that targeting the described pathways by administering beneficial substances during the perinatal period can counteract the effects of programming, prevent or reduce the abnormal development and, therefore, reduce the risk of CVD in adult life. Different nutritional interventions in perinatal and early postnatal life can revert or alleviate the cardiovascular consequences of IUGR programming. For example, supplementation with vitamin $\mathrm{C}$, vitamin $\mathrm{E}$ and NO has been shown to reduce blood pressure and prevent proteinuria in rats [109]. On the other hand, inhibition of certain factors can also improve cardiovascular health as well, as shown for NF- $\kappa$ B inhibitor pyrrolidine dithiocarbamate and soluble epoxide hydrolase inhibitor 12-(3-adamantan-1-yl-ureido)dodecanoic acid, which significantly reduce blood pressure in perinatal treated off- 
spring of spontaneously hypertensive rats $[110,111]$. It has also been shown that IUGR fetal programming induced by a low-protein diet in rats can be reversed or even prevented by co-treatments with urea, which normalized body weight, or with glycine, which prevented an increase in blood pressure [112]. These findings support the importance of nitrogen for healthy development and growth of the fetus. Similar results have been obtained in rats fed a low-protein diet by various other treatments, like perinatal administration of folate [113], metyrapone (11ß-hydroxylase inhibitor) [114] or lazaroid (an inhibitor of lipid peroxidation) [115], as well as postnatal treatment with fish oil ( $\omega-3$ polyunsaturated fatty acids) [116] or atorvastatin (cholesterol-lowering and anti-atherosclerotic drug) [117].

It is clear that further intensive research is still needed to fully understand the mechanisms of fetal programming and its precise timing. The progress that has been made so far, however, seems very promising for successful development of early intervention therapies to prevent and maybe even reverse CVD later in life.

\section{Clinical Implications}

The conclusion that can be drawn from the known data is that IUGR has a very strong association not only with metabolic, but also with primary cardiovascular programming, that lead to the long-term adverse consequences in later life (fig. 2). Therefore, it is of utmost importance not only to identify the onset of IUGR as early as possible, but also to follow up patients in adulthood in order to manage and improve their cardiovascular health condition.

Although current clinical guidelines still do not include IUGR as a risk factor for CVD, it is recommended to perform thorough screening for hypertension in children in order to provide strategies to improve and maintain cardiovascular health [118]. Hypertension and prehypertension in the child has been associated with substantial long-term health risks and considered an indication for lifestyle modifications. Close monitoring together with lifestyle (promoting physical activity and lack of exposure to secondary smoking or obesity) and dietary interventions have demonstrated to improve cardiovascular health in hypertensive children [118]. In particular, a high intake of dietary long-chain $\omega-3$ fatty acids is associated with lower blood pressure and may prevent progression of subclinical atherosclerosis in children born with low birth weight $[119,120]$. A recent randomized trial in a large cohort of children suggests that the

Follow-Up of Intrauterine Growth

Restriction

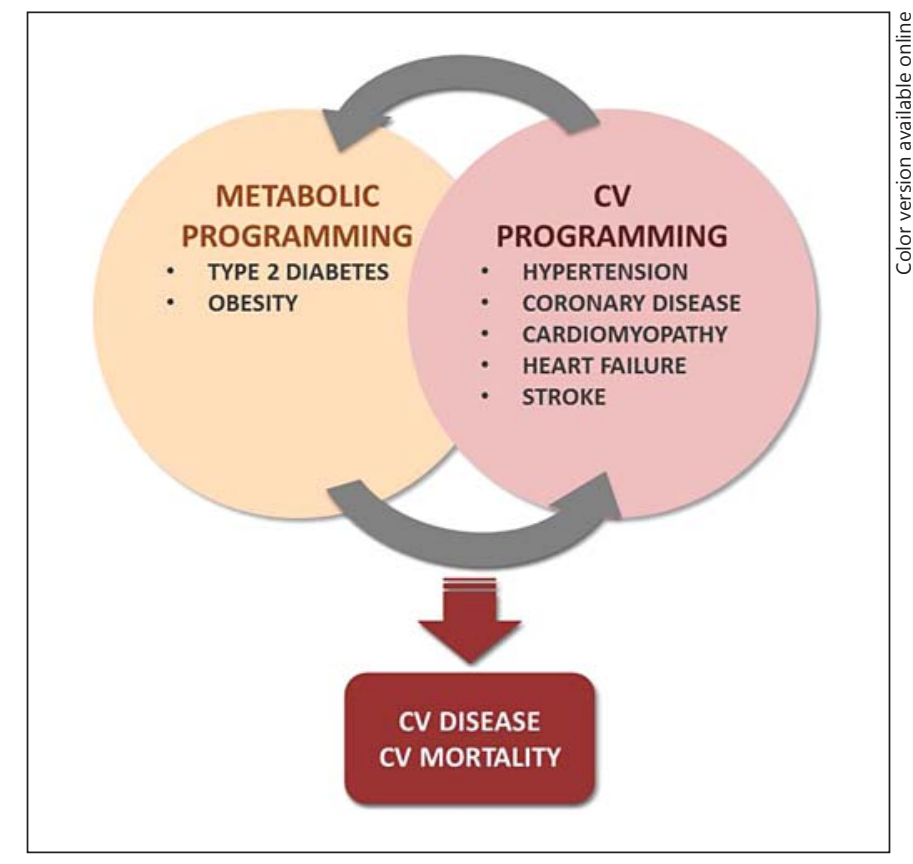

Fig. 2. Long-term cardiovascular consequences of IUGR. The complex interconnection of cardiovascular and metabolic programming in IUGR can lead to adverse outcomes in postnatal life, including CVD and mortality. A thorough follow-up of the patients is highly important to prevent long-term consequences of IUGR.

inverse association of fetal growth with arterial wall thickness in childhood can be prevented by dietary $\omega-3$ fatty acid supplementation over the first 5 years of life [121].

However, it is critical to adequately select the high-risk population that may benefit from these therapeutic strategies. The severity of IUGR is currently defined mainly by gestational age and birth centile, which are inversely related to perinatal and neurodevelopmental outcomes [122-125]. For further antepartum surveillance of the IUGR-viable fetus, umbilical artery Doppler has been proposed to be used, thus significantly decreasing the necessity of labor induction, delivery via cesarean section, and perinatal death [126]. However, as mentioned earlier, cardiovascular programming occurs not only in premature and severe IUGR cases, but also in mild late-onset IUGR cases with normal umbilical artery parameters $[18,45,49$, 127]. Therefore, standard perinatal parameters such as gestational age, birth weight centile or umbilical Doppler show a poor performance for predicting long-term cardiovascular outcome. A recent prospective study has pointed out fetal echocardiography as a promising tool for the early identification of those IUGR cases with postnatal hypertension and arterial remodeling $[128,129]$. 
Taken together, there is accumulating and highly significant evidence that supports the importance to followup IUGR patients into their adulthood. Considering the strong prevalence of IUGR, it is of utmost clinical relevance to detect cardiovascular risks as early as possible, to introduce timely preventive interventions and to adapt the lifestyle in order to improve the long-term cardiovascular health outcome and the quality of life of IUGR patients.

\section{Conclusions}

IUGR is a very complex and multifactorial disorder affecting the fetal development rate that often results in multiple adverse peri- and postnatal complications in- cluding death. The strong evidence discussed in this review proves the consistent long-term persistence of CVD in patients who suffered IUGR early in life. Considering the high prevalence of IUGR and the progressing availability of intervention strategies, it is critical to detect cardiovascular risks as early as possible, to introduce timely preventive interventions and to adapt the lifestyle in order to improve the long-term cardiovascular health outcome of IUGR cases. Although there are still no general pediatric guidelines used in clinical practice, the implementation of correct follow-up and management could help high-risk patients who suffered from IUGR tremendously. Therefore, based on the collective research data known today, such guidelines ideally should be developed and introduced into clinical practice as soon as possible.

\section{References}

1 European Heart Network: European Cardio- 11 Committee on Practice Bulletins Gynecology, vascular Disease Statistics 2008.

-2 Berenson GS: Childhood risk factors predict adult risk associated with subclinical cardiovascular disease. The Bogalusa Heart Study. Am J Cardiol 2002;90:3L-7L.

- 3 Barker DJ, Osmond C, Golding J, Kuh D, Wadsworth ME: Growth in utero, blood pressure in childhood and adult life, and mortality from cardiovascular disease. BMJ 1989; 298:564-567.

4 Barker DJ: Fetal origins of coronary heart disease. BMJ 1995;311:171-174.

5 Tintu A, Rouwet E, Verlohren S, Brinkmann J, Ahmad S, Crispi F, van Bilsen M, Carmeliet P, Staff AC, Tjwa M, Cetin I, Gratacos E, Hernandez-Andrade E, Hofstra L, Jacobs M, Lamers WH, Morano I, Safak E, Ahmed A, le Noble F: Hypoxia induces dilated cardiomyopathy in the chick embryo: mechanism, intervention, and long-term consequences. PLoS One 2009;4:e5155.

6 Gluckman PD: Developmental origins of disease paradigm: a mechanistic and evolutionary perspective. Pediatr Res 2004;56: 311-317.

7 Palinski W, Napoli C: Impaired fetal growth, cardiovascular disease, and the need to move on. Circulation 2008;117:341-343.

8 Phillips D: Insulin resistance as a programmed response to fetal undernutrition. Diabetologia 1996;39:1119-1122.

-9 Gluckman PD, Hanson MA, Cooper C, Thornburg KL: Effect of in utero and earlylife conditions on adult health. $\mathrm{N}$ Engl J Med 2008;359:61-73.

10 Diderholm B: Perinatal energy metabolism with reference to IUGR and SGA: studies in pregnant women and newborn infants. Indian J Med Res 2009;130:612-617. American College of Obstetricians and Gynecologists: Intrauterine growth restriction. Clinical management guidelines for obstetrician-gynecologists. Int J Gynecol Obstet 2001; 72:85-96.

12 Alberry M, Soothill P: Management of fetal growth restriction. Arch Dis Child Fetal Neonatal Ed 2007;92:62-67.

13 Baschat AA: Fetal responses to placental insufficiency: an update. BJOG 2004;111:10311041.

14 Hecher K, Bilardo CM, Stigter RH, Ville Y, Hackelöer BJ, Kok HJ, Senat MV, Visser GH: Monitoring of fetuses with intrauterine growth restriction: a longitudinal study. Ultrasound Obstet Gynecol 2001;18:564-570.

15 Baschat AA: Neurodevelopment following fetal growth restriction and its relationship with antepartum parameters of placental dysfunction. Ultrasound Obstet Gynecol 2011;37: 501-514.

16 Baschat AA: Fetal growth restriction - from observation to intervention. J Perinat Med 2010;38:239-246.

17 Hecher K, Campbell S, Doyle P, Harrington $\mathrm{K}$, Nicolaides K: Assessment of fetal compromise by Doppler ultrasound investigation of the fetal circulation: arterial, intracardiac, and venous blood flow velocity studies. Circulation 1995;91:129-138.

18 Crispi F, Hernandez-Andrade E, Pelsers MM, Plasencia W, Benavides-Serralde JA, Eixarch E, Le Noble F, Ahmed A, Glatz JF, Nicolaides $\mathrm{KH}$, Gratacos E: Cardiac dysfunction and cell damage across clinical stages of severity in growth-restricted fetuses. Am J Obstet Gynecol 2008; 199:254.e1-e8.

19 Comas M, Crispi F, Cruz-Martinez R, Martinez JM, Figueras F, Gratacós E: Usefulness of myocardial tissue Doppler vs. conventional echocardiography in the evaluation of cardiac dysfunction in early-onset intrauterine growth restriction. J Obstet Gynecol 2010; 203:45.e1-e7.

20 Kiserud T, Kessler J, Ebbing C, Rasmussen S: Ductus venosus shunting in growth-restricted fetuses and the effect of umbilical circulatory compromise. Ultrasound Obstet Gynecol 2006;28:143-149.

21 Iruretagoyena JY, Torre I, Amat-Roldan I, Psilodimitrakopoulos S, Crispi F, Garcia-Canadilla P, Gonzalez-Tendero A, Nadal A, Eixarch E, Loza-Alvarez P, Artigas D, Gratacos E: Ultrastructural analysis of myocardiocyte sarcomeric changes in relation with cardiac dysfunction in human fetuses with intrauterine growth restriction. Am J Obstet Gynecol 2011;204:S34.

22 Bijnens B, Cikes M, Butakoff C, Sitges M, Crispi F: Myocardial motion and deformation: what does it tell us and how does it relate to function? Fetal Diagn Ther 2012;32:5-16.

23 Huxley RR, Shiell AW, Law CM: The role of size at birth and postnatal catch-up growth in determining systolic blood pressure: a systematic review of the literature. J Hypertens 2000;18:815-831.

24 Perk J, De Backer G, Gohlke H, Graham I, Reiner Z, Verschuren WM, Albus C, Benlian P, Boysen G, Cifkova R, Deaton C, Ebrahim S, Fisher M, Germanò G, Hobbs R, Hoes A, Karadeniz S, Mezzani A, Prescott E, Ryden L, Scherer M, Syvanne M, et al: European guidelines on cardiovascular disease prevention in clinical practice. Eur Heart J 2012;33:1635-1701.

25 Skilton MR, Ayer JG, Harmer JA, Webb K, Leeder SR, Marks GB, Celermajer DS: Impaired fetal growth and arterial wall thickening. A randomized trial of omega-3 supplementation. Pediatrics 2012;129:e698. 
-26 Estruch R, Ros E, Salas-Salvadó J, Covas MI, Corella D, Arós F, Gómez-Gracia E, RuizGutiérrez V, Fiol M, Lapetra J, LamuelaRaventos RM, Serra-Majem L, Pintó X, Basora J, Muñoz MA, Sorlí JV, Martínez JA, Martínez-González MA: Primary prevention of cardiovascular disease with a Mediterranean diet. N Engl J Med 2013;368:1279_ 1290.

27 Gennser G, Rymark P, Isberg PE: Low birth weight and risk of high blood pressure in adulthood. Bone Miner J 1988;296:14981500.

-28 Leon DA, Johansson M, Rasmussen F: Gestational age and growth rate of fetal mass are inversely associated with systolic blood pressure in young adults: an epidemiologic study of 165,136 Swedish men aged 18 years. Am J Epidemiol 2000;152:597-604.

29 Martyn CN, Barker DJ, Jespersen S, Greenwald S, Osmond C, Berry C: Growth in utero, adult blood pressure, and arterial compliance. Br Heart J 1995;73:116-121.

- 30 Hales CN, Barker DJ, Clark PM, Cox LJ, Fall C, Osmond C, Winter PD: Fetal and infant growth and impaired glucose tolerance at age 64. BMJ 1991;303:1019-1022.

- 31 Curhan GC, Willett WC, Rimm EB, Spiegelman D, Ascherio AL, Stampfer MJ: Birth weight and adult hypertension, diabetes mellitus, and obesity in US men. Circulation 1996;94:3246-3250.

-32 Joseph KS, Kramer MS: Review of the evidence on fetal and early childhood antecedents of adult chronic disease. Epidemiol Rev 1996; 18:158-174.

-33 Leon DA, Lithell HO, Vâgerö D, Koupilová I, Mohsen R, Berglund L, Lithell UB, McKeigue PM: Reduced fetal growth rate and increased risk of death from ischemic heart disease: cohort study of 15,000 Swedish men and women born 1915-29. BMJ 1998;317:241-245.

- 34 Rich-Edwards JW, Stampfer MJ, Manson JE, Rosner B, Hankinson SE, Colditz GA, Willett WC, Hennekens $\mathrm{CH}$ : Birth weight and risk of cardiovascular disease in a cohort of women followed up since 1976. BMJ 1997;315:369400.

-35 Barker DJ, Winter PD, Osmond C, Margetts $\mathrm{B}$, Simmonds SJ: Weight in infancy and death from ischemic heart disease. Lancet 1989;2: 577-580.

- 36 Osmond C, Barker DJ, Winter PD, Fall CH, Simmonds SJ: Early growth and death from cardiovascular disease in women. BMJ 1993; 307:1519-1524.

- 37 Eriksson JG, Forsén T, Tuomilehto J, Osmond C, Barker DJ: Early growth and coronary heart disease in later life: longitudinal study. Bone Miner J 2001;322:949-953.

- 38 Eriksson JG, Forsén T, Tuomilehto J, Winter PD, Osmond C, Barker DJ: Catch-up growth in childhood and death from coronary heart disease: longitudinal study. Bone Miner J 1999;318:427-431.

- 39 Forsén T, Eriksson JG, Tuomilehto J, Teramo $\mathrm{K}$, Osmond C, Barker DJ: Mother's weight in pregnancy and coronary heart disease in a cohort of Finish men: follow-up study. Bone Miner J 1997;315:837-840.

40 Forsén T, Eriksson JG, Tuomilehto J, Osmond C, Barker DJ: Growth in utero and during childhood among women who develop coronary heart disease: longitudinal study. Bone Miner J 1999;319:1403-1407.

41 Levitt NS, Lambert EV, Woods D, Hales CN, Andrew R, Seckl JR: Impaired glucose tolerance and elevated blood pressure in low birth weight, nonobese, young south African adults: early programming of cortisol axis. J Clin Endocrinol Metab 2000;85:46114618.

42 Law CM, Shiell AW: Is blood pressure inversely related to birth weight? The strength of evidence from a systematic review of the literature. J Hypertens 1996;14:935-941.

43 Nilsson PM, Ostergren PO, Nyberg P, Söderström M, Allebeck P: Low birth weight is associated with elevated systolic blood pressure in adolescence: a prospective study of a birth cohort of 149,378 Swedish boys. J Hypertens 1997; 15:1627-1631.

44 Verburg BO, Jaddoe VW, Wladimiroff JW, Hofman A, Witteman JC, Steegers EA: Fetal hemodynamic adaptive changes related to intrauterine growth: the Generation R Study. Circulation 2008;117:649-659.

45 Comas M, Crispi F, Cruz-Martinez R, Figueras F, Gratacos E: Tissue Doppler echocardiographic markers of cardiac dysfunction in small-for-gestational age fetuses. Am J Obstet Gynecol 2011;205:57.e1-e6.

-46 Cruz-Martinez R, Figueras F, Hernandez-Andrade E, Oros D, Gratacos E: Changes in myocardial performance index and aortic isthmus and ductus venosus Doppler in term, smallfor-gestational age fetuses with normal umbilical artery pulsatility index. Ultrasound Obstet Gynecol 2011;38:400-405.

47 Figueras F, Eixarch E, Gratacos E, Gardosi J: Predictiveness of antenatal umbilical artery Doppler for adverse pregnancy outcome in small-for-gestational-age babies according to customised birth weight centiles: population-based study. BJOG 2008;115:590594.

48 Soothill PW, Bobrow CS, Holmes R: Small for gestational age is not a diagnosis. Ultrasound Obstet Gynecol 1999;13:225-228.

49 Crispi F, Figueras F, Cruz-Lemini M, Bartrons J, Bijnens B, Gratacos E: Cardiovascular programming in children born small for gestational age and relationship with prenatal signs of severity. Am J Obstet Gynecol 2012; 207:121.e1-e9.

-50 Zanardo V, Visentin S, Trevisanuto D, Bertin M, Cavallin F, Cosmi E: Fetal aortic wall thickness: a marker of hypertension in IUGR children? Hypertens Res 2013, E-pub ahead of print.

51 Villar J, Belizan JM: The timing factor in the pathophysiology of the intrauterine growth retardation syndrome. Obstet Gynecol Surv 1982;37:499-506.
52 Ergaz Z, Avgil M, Ornoy A: Intrauterine growth restriction - etiology and consequences: what do we know about the human situation and experimental animal models? Reprod Toxicol 2005;20:301-322.

53 Ozaki T, Nishina H, Hanson MA, Poston L: Dietary restriction in pregnant rats causes gender-related hypertension and vascular dysfunction in offspring. J Physiol 2001;530: 141-152.

54 Vickers MH, Breier BH, Cutfield WS, Hofman PL, Gluckman PD: Fetal origins of hyperphagia, obesity, and hypertension and postnatal amplification by hypercaloric nutrition. Am J Physiol Endocrinol Metab 2000;279:E83-E87.

55 Barnes SK, Ozanne SE: Pathways linking the early environment to long-term health and lifespan. Prog Biophys Mol Biol 2011;106: 323-336.

56 Tarry-Adkins JL, Ozanne SE: Mechanisms of early life programming: current knowledge and future directions. J Clin Nutr 2011; 96(suppl):1765S-1771S.

57 Garofano A, Czernichow P, Bréant B: Postnatal somatic growth and insulin contents in moderate or severe intrauterine growth retardation in the rat. Biol Neonate 1998;73:8998.

58 McMillen IC, Robinson JS: Developmental origins of the metabolic syndrome: prediction, plasticity, and programming. Physiol Rev 2005;85:571-633.

59 Langley SC, Jackson AA: Increased systolic blood pressure in adult rats induced by fetal exposure to maternal low-protein diets. Clin Sci (Lond) 1994;86:217-222.

60 Snoeck A, Remacle C, Reusens B, Hoet JJ: Effect of a low-protein diet during pregnancy on the fetal rat endocrine pancreas. Biol Neonate 1990;57:2107-2118.

61 Nuyt AM, Alexander BT: Developmental programming and hypertension. Curr Opin Nephrol Hypertens 2009; 18:144-152.

62 Watkins AJ, Lucas ES, Torrens C, Cleal JK, Green L, Osmond C, Eckert JJ, Gray WP, Hanson MA, Fleming TP: Maternal low-protein diet during mouse preimplantation development induces vascular dysfunction and altered renin-angiotensin-system homeostasis in the offspring. Br J Nutr 2010;103:17621770.

-63 Nishina H, Green LR, McGarrigle HH, et al: Effect of nutritional restriction in early pregnancy on isolated femoral artery function in mid-gestation fetal sheep. J Physiol 2003;553: 637-647.

64 Langley-Evans SC, Welham SJ, Sherman RC, Jackson AA: Weanling rats exposed to maternal low-protein diets during discrete periods of gestation exhibit differing severity of hypertension. Clin Sci 1996;91:607-615.

65 Huizinga CT, Engelbregt MJ, Rekers-Mombarg LT, Vaessen SF, Delemarre-van de Waal HA, Fodor M: Ligation of the uterine artery and early postnatal food restriction - animal models for growth retardation. Horm Res 2004;62:233-240.
Follow-Up of Intrauterine Growth Restriction
Fetal Diagn Ther 2014;36:143-153 DOI: $10.1159 / 000353633$ 
66 Wigglesworth JS: Experimental growth retardation in the fetal rat. Am J Obstet Gynecol 1964;88:1-13.

67 Briscoe TA, Rehn AE, Dieni S, Duncan JR, Wlodek ME, Owens JA, Rees SM: Cardiovascular and renal disease in the adolescent guinea pig after chronic placental insufficiency. Am J Obstet Gynecol 2004;191:847-855.

-68 Lafeber HN, Rolph TP, Jones CT: Studies on the growth of the fetal guinea pig. The effects of ligation of the uterine artery on organ growth and development. J Dev Physiol 1984; 6:441-459.

-69 Jones CT, Lafeber HN, Roebuck MM: Studies on the growth of the fetal guinea pig. Changes in plasma hormone concentration during normal and abnormal growth. J Dev Physiol 1984;6:461-472.

-70 Rehn AE, Van Den Buuse M, Copolov D, Briscoe T, Lambert G, Rees S: An animal model of chronic placental insufficiency: relevance to neurodevelopmental disorders including schizophrenia. Neuroscience 2004; 129:381-391.

-71 Eixarch E, Hernandez-Andrade E, Crispi F, Illa M, Torre I, Figueras F, Gratacos E: Impact on fetal mortality and cardiovascular Doppler of selective ligature of uteroplacental vessels compared with undernutrition in rabbit model of IUGR. Placenta 2011;32: 304-309.

-72 Anthony RV, Scheaffer AN, Wright CD, Regnault TR: Ruminant models of prenatal growth restriction. Reprod Suppl 2003;61: 183-194.

73 Morrison JL: Sheep models of intrauterine growth restriction: fetal adaptations and consequences. Clin Exp Pharmacol Physiol 2008; 35:730-743.

74 Langley-Evans SC: Hypertension induced by fetal exposure to a maternal low-protein diet, in the rat, is prevented by pharmacological blockage of maternal glucocorticoid synthesis. J Hypertens 1997; 15:537-544.

75 Nyirenda MJ, Lindsay RS, Kenyon CJ, Burchell A, Seckl JR: Glucocorticoid exposure in late gestation permanently programs rat hepatic phosphoenolpyruvate carboxykinase and glucocorticoid receptor expression and causes glucose intolerance in adult offspring. J Clin Invest 1998;101:2174-2181.

76 Newnham JP: Is prenatal glucocorticoid administration another origin of adult disease? Clin Exp Pharmacol Physiol 2001;28:957-961.

-77 Benediktsson R, Lindsay RS, Noble J, Seckl JR, Edwards CR: Glucocorticoid exposure in utero: new model for adult hypertension. Lancet 1993;341:339-341.

78 Levitt NS, Lindsay RS, Holmes MC, Seckl JR: Dexamethasone in the last week of pregnancy attenuates hippocampal glucocorticoid receptor gene expression and elevates blood pressure in the adult offspring. Neuroendocrinology 1996;64:412-418.

-79 Lindsay RS, Lindsay RM, Edwards CR, Seckl JR: Inhibition of $11 \beta$-Hydroxysteroid dehydrogenase in pregnant rats and the program- ming of blood pressure in offspring. Hypertension 1996;27:1200-1204

-80 Langley-Evans SC, Phillips GJ, Benediktsson R, Gardner DS, Edwards CR, Jackson AA, Seckl JR: Protein intake in pregnancy, placental glucocorticoid metabolism and the programming of hypertension in the rat. Placenta $1996 ; 173: 169-172$.

81 Lesage J, Blondeau B, Grino M, Bréant B, Dupouy JP: Maternal undernutrition during late gestation induces fetal overexposure to glucocorticoids and intrauterine growth retardation, and disturbs the hypothalamo-pituitary axis in the newborn rat. Endocrinology 2001;142:1692-1702.

82 Dwyer CM, Stickland NC: The effects of maternal undernutrition on maternal and fetal serum insulin-like growth factors, thyroid hormones and cortisol in the guinea pig. J Dev Physiol 1992;18:303-313.

-83 Edwards CR, Benediktsson R, Lindsay RS, Seckl JR: Dysfunction of placental glucocorticoid barrier: link between fetal environment and adult hypertension? Lancet 1993;341: 355-357.

84 Moore LG: Altitude-aggravated illness: examples from pregnancy and prenatal life. Ann Emerg Med 1987;16:965-973.

85 Bae S, Xiao Y, Li G, Casiano CA, Zhang L: Effect of maternal chronic hypoxic exposure during gestation in apoptosis in fetal heart. Am J Physiol Heart Circ Physiol 2003; 285:H983-H990.

86 Li G, Xiao Y, Estrella JL, Ducsay CA, Gilbert $\mathrm{RD}$, Zhang L: Effect of fetal hypoxia on heart susceptibility to ischemia and reperfusion injury in the adult rat. J Soc Gynecol Invest 2003;10:265-274.

87 Bernstein IM, Mongeon JA, Badger GJ, Solomon L, Heil SH, Higgins ST: Maternal smoking and its association with birth weight. Obstet Gynecol 2005;106:986-991.

88 Jaddoe VW, Verburg BO, de Ridder MA, Hofman A, Mackenbach JP, Moll HA, Steegers EA, Witteman JC: Maternal smoking and fetal growth characteristics in different periods of pregnancy: the Generation $\mathrm{R}$ Study. Am J Epidemiol 2007;165:1207-1215.

89 Larsen LG, Clausen HV, Jønsson L: Stereologic examination of placentas from mothers who smoke during pregnancy. Am J Obstet Gynecol 2002;186:531-537.

90 Blake KV, Gurrin LC, Evans SF, Beilin LJ, Landau LI, Stanley FJ, Newnham JP: Maternal cigarette smoking during pregnancy, low birth weight and subsequent blood pressure in early childhood. Early Hum Dev 2000;57:137-147.

-91 Brion MJ, Leary SD, Lawlor DA, Smith GD, Ness AR: Modifiable maternal exposures and offspring blood pressure: a review of epidemiological studies of maternal age, diet, and smoking. Pediatr Res 2008;63:593-598.

92 Leichter J: Decreased birth weight and attainment of postnatal catch-up growth in offspring of rats exposed to cigarette smoke during gestation. Growth Dev Aging 1995;59: 63-66.
93 Younoszai MK, Peloso J, Haworth JC: Fetal growth retardation in rats exposed to cigarette smoke during pregnancy. Am J Obstet Gynecol 1969;104:1207-1213.

-94 Carter RC, Jacobson JL, Sokol RJ, Avison MJ, Jacobson SW: Fetal alcohol-related growth restriction from birth through young adulthood and moderating effects of maternal prepregnancy weight. Alcohol Clin Exp Res 2013;37:452-456.

95 Bateman DA, Ng SK, Hansen CA, Heagarty MC: The effects of intrauterine cocaine exposure in newborns. Am J Public Health 1993;83:190-193.

-96 Ponnappa BC, Rubin E: Modeling alcohol's effects on organs in animal models. Alcohol Res Health 2000;24:93-104.

-97 Sebert S, Sharkey D, Budge H, Symonds ME: The early programming of metabolic health: is epigenetic setting the missing link? Am J Clin Nutr 2011;94:1953S-1958S.

-98 McMullen S, Langley-Evans SC, Gambling L, Lang C, Swali A, McArdle HJ: A common cause for a common phenotype: the gatekeeper hypothesis in fetal programming. Med Hypotheses 2012;78:88-94.

-99 Rogers LK, Velten M: Maternal inflammation, growth retardation, and preterm birth: insights into adult cardiovascular disease. Life Sci 2011;89:417-421.

100 Canani RB, Costanzo MD, Leone L, Bedogni G, Brambilla P, Cianfarani S, Nobili V, Pietrobelli A, Agostoni C: Epigenetic mechanisms elicited by nutrition in early life. Nutr Res Rev 2011;24:198-205.

101 Santos F, Dean W: Epigenetic reprogramming during early development in mammals. Reproduction 2004;127:643-651.

102 McKay JA, Mathers JC: Diet-induced epigenetic changes and their implications for health. Acta Physiol (Oxf) 2011;202:103118.

103 Vaiman D, Gascoin-Lachambre G, Boubred F, Mondon F, Feuerstein JM, Ligi I, Grandvuillemin I, Barbaux S, Ghigo E, Achard V, Simeoni U, Buffat C: The intensity of IUGRinduced transcriptome deregulations is inversely correlated with the onset of organ function in a rat model. PLoS One 2011; 6:e21222.

104 Langley-Evans SC, Welham SJ, Jackson AA: Fetal exposure to a maternal low-protein diet impairs nephrogenesis and promotes hypertension in the rat. Life Sci 1999;64: 965-974.

105 Nuyt AM: Mechanisms underlying developmental programming of elevated blood pressure and vascular dysfunction: evidence from human studies and experimental animal models. Clin Sci (Lond) 2008;114:1-17.

106 Franco MC, Ponzio BF, Gomes GN, Gil FZ, Tostes R, Carvalho MH, Fortes ZB: Micronutrient prenatal supplementation prevents the development of hypertension and vascular endothelial damage induced by intrauterine malnutrition. Life Sci 2009;85:327333. 
107 Moritz KM, Singh RR, Probyn ME, Denton KM: Developmental programming of a reduced nephron endowment: more than just a baby's birth weight. Am J Physiol Renal Physiol 2009;296:F1-F9.

108 Baum M: Role of the kidney in the prenatal and early postnatal programming of hypertension. Am J Physiol Renal Physiol 2010; 298:F235-F247.

109 Racasan S, Braam B, Koomans HA, Joles JA: Programming blood pressure in adult SHR by shifting perinatal balance of $\mathrm{NO}$ and reactive oxygen species toward NO: the inverted Barker phenomenon. Am J Physiol Renal Physiol 2005;288:F626-F636.

110 Koeners MP, Braam B, Joles JA: Perinatal inhibition of NF- $\kappa B$ has long-term antihypertensive effects in spontaneously hypertensive rats. J Hypertens 2011;29:1160-1166.

-111 Koeners MP, Wesseling S, Ulu A, Sepúlveda RL, Morisseau C, Braam B, Hammock BD, Joles JA: Soluble epoxide hydrolase in the generation and maintenance of high blood pressure in spontaneously hypertensive rats. Am J Physiol Endocrinol Metab 2011; 300:E691-E698.

-112 Jackson AA, Dunn RL, Marchand MC, Langley-Evans SC: Increased systolic blood pressure in rats induced by a maternal lowprotein diet is reversed by dietary supplementation with glycine. Clin Sci (Lond) 2002; 103:633-639.

113 Torrens C, Brawley L, Anthony FW, Dance CS, Dunn R, Jackson AA, Poston L, Hanson MA: Folate supplementation during pregnancy improves offspring cardiovascular dysfunction induced by protein restriction. Hypertension 2006;47:982-987.

$\checkmark 114$ Bogdarina I, Haase A, Langley-Evans S, Clark AJ: Glucocorticoid effects on the programming of AT1b angiotensin receptor gene methylation and expression in the rat. PLoS One 2010;5:e9237.
115 Cambonie G, Comte B, Yzydorczyk C, Ntimbane T, Germain N, Lê NL, Pladys P, Gauthier C, Lahaie I, Abran D, Lavoie JC, Nuyt AM: Antenatal antioxidant prevents adult hypertension, vascular dysfunction, and microvascular rarefaction associated with in utero exposure to a low-protein diet. Am J Physiol Regul Integr Comp Physiol 2007;292:R1236-R1245.

116 Catta-Preta M, Oliveira DA, Mandarim-deLacerda CA, Aguila MB: Adult cardiorenal benefits from postnatal fish oil supplement in rat offspring of low-protein pregnancies. Life Sci 2006;80:219-229.

117 Bezerra DG, Lacerda Andrade LM, Pinto da Cruz FO, Mandarim-de-Lacerda CA: Atorvastatin attenuates cardiomyocyte loss in adult rats from protein-restricted dams. J Card Fail 2008;14:151-160.

118 Williams CL, Hayman LL, Daniels SR, Robinson TN, Steinberger J, Paridon S, Bazzarre T: Cardiovascular health in childhood: a statement for health professionals from the Committee on Atherosclerosis, Hypertension, and Obesity in the Young (AHOY) of the Council on Cardiovascular Disease in the Young, American Heart Association. Circulation 2002;106:143-160.

119 Skilton MR, Raitakari OT, Celermajer DS: High intake of dietary long-chain $\omega-3$ fatty acids is associated with lower blood pressure in children born with low birth weight: NHANES 2003-2008. Hypertension 2013; 61:972-976.

120 Skilton MR, Mikkilä V, Würtz P, Ala-Korpela M, Sim KA, Soininen P, Kangas AJ, Viikari JS, Juonala M, Laitinen T, Lehtimäki T, Taittonen L, Kähönen M, Celermajer DS, Raitakari OT: Fetal growth, omega-3 $(\omega-3)$ fatty acids, and progression of subclinical atherosclerosis: preventing fetal origins of disease? The Cardiovascular Risk in Young Finns Study. Am J Clin Nutr 2013; 97:58-65.

121 Skilton MR, Ayer JG, Harmer JA, Webb K, Leeder SR, Marks GB, Celermajer DS: Impaired fetal growth and arterial wall thickening: a randomized trial of $\omega-3$ supplementation. Pediatrics 2012;129:e698-e703.
22 Rossi P, Tauzin L, Marchand E, Boussuges A, Gaudart J, Frances Y: Respective roles of preterm birth and fetal growth restriction in blood pressure and arterial stiffness in adolescence. J Adolesc Health 2011;48:520-522.

123 Savchev S, Figueras F, Cruz-Martinez R, Illa M, Botet F, Gratacos E: Estimated weight centile as a predictor of perinatal outcome in small-for-gestational-age pregnancies with normal fetal and maternal Doppler indices. Ultrasound Obstet Gynecol 2012;39:299303.

124 Cruz-Lemini M, Crispi F, Van Mieghem T, Pedraza D, Cruz-Martínez R: Acosta-Rojas R, Figueras F, Parra-Cordero M, Deprest J, Gratacós E. Risk of perinatal death in earlyonset intrauterine growth restriction according to gestational age and cardiovascular Doppler indices: a multicenter study. Fetal Diagn Ther 2012;32:116-122.

125 Figueras F, Gardosi J: Intrauterine growth restriction: new concepts in antenatal surveillance, diagnosis, and management. Am J Obstet Gynecol 2011;204:288-300.

126 Berkley E, Chauhan SP, Abuhamad A: Doppler assessment of the fetus with intrauterine growth restriction. Am J Obstet Gynecol 2012;206:300-308.

127 Crispi F, Bijnens B, Figueras F, Bartrons J, Eixarch E, Le Noble F, Ahmed A, Gratacós E: Fetal growth restriction results in remodeled and less efficient hearts in children. Circulation 2010;121:2427-2436.

128 Cruz-Lemini M, Crispi F, Valenzuela-Alcaraz B, Figueras F, Gomez O, Sitges M, Bijnens B, Gratacos E: A fetal cardiovascular score to predict infant hypertension and arterial remodeling in intrauterine growth restriction (in preparation).

129 Crispi F, Gratacós E: Fetal cardiac function: technical considerations and potential research and clinical applications. Fetal Diagn Ther 2012;32:47-64. 